\title{
INEXPENSIVE PROBES FOR THE DETERMINATION OF BODY TEMPERATURE
}

\author{
C. J. GORE, BEd (Hons), R. T. WITHERS, PhD, MSc, DPE, G. F. WOODS and L. DAY \\ School of Education, The Flinders University of South Australia
}

\section{ABSTRACT}

Two-terminal integrated circuit temperature transducers (Analog Devices' AD 590) were used to fabricate skin and rectal probes for the monitoring of mean body temperature. They are inexpensive, robust, easily constructed and of low mass. The skin sensor system described is capable of being solidly attached regardless of the body contour such that it remains integral throughout profuse sweating and vigorous movement. Both types of probe are stable, accurate to within $\pm 0.05^{\circ} \mathrm{C}$ over the physiological range of measurement and exhibit $100 \%$ response times of approximately $60 \mathrm{~s}$ to a square wave stimulus of $10^{\circ} \mathrm{C}$.

Key Words: Integrated circuit temperature transducers, Body temperature.

\section{INTRODUCTION}

The mean body temperature can be estimated using the following formula proposed by Burton (1935):

$$
\overline{\mathrm{T}}_{\text {body }}=.65 \mathrm{~T}_{\text {rectal }}+.35 \overline{\mathrm{T}}_{\text {skin }}
$$

The core temperature is measured by a probe inserted 14 $\mathrm{cm}$ into the rectum while the mean skin temperature is computed by weighting observations from the chest, arm, thigh and calf (Ramanathan, 1964). However, the unavailability of an inexpensive temperature monitoring instrument with simultaneous digital readouts of multiple channels which could be interfaced with a microcomputer prompted us to fabricate our own. This paper describes how the two-terminal integrated circuit temperature transducers recommended by Nicholls (1983), and which he maintains are superior to the more traditional thermistors and thermocouples, can be adapted to monitor rectal and skin temperatures.

\section{CONSTRUCTION}

Details of the materials and components are presented in Table I. After mounting the AD 590 transducer on the probe holder, the connecting cable was soldered and the whole assembly rendered waterproof by potting it in the sealing compound. This is important since only one microamp of leakage will cause a one degree error. The thermal inertia of the sensor should be minimised by limiting the thickness of the sealing compound to $1 \mathrm{~mm}$. This can be accomplished by filing the cured sealing compound on top of the can to the desired thickness. Due to circuit configuration, the $A D 590$ transducer floats at $-5 \mathrm{~V}$ with reference to equipment ground. Thus failure to insulate will result in mild discomfort. While a 3 wire system would maintain the AD 590 transducer at earth potential and therefore eliminate the need to pot the top of the can, complete encapsulation was considered the best method of preserving the overall integrity of the customised sensor.

\section{SKIN PROBE}

The skin probe holders were fabricated from $1.5 \mathrm{~mm}$ thick PVC sheeting and the whole assembly was attached to the

Address for correspondence:

Dr. R. T. Withers

The Exercise Physiology Laboratory

School of Education

The Flinders University of South Australia

Bedford Park

South Australia 5042

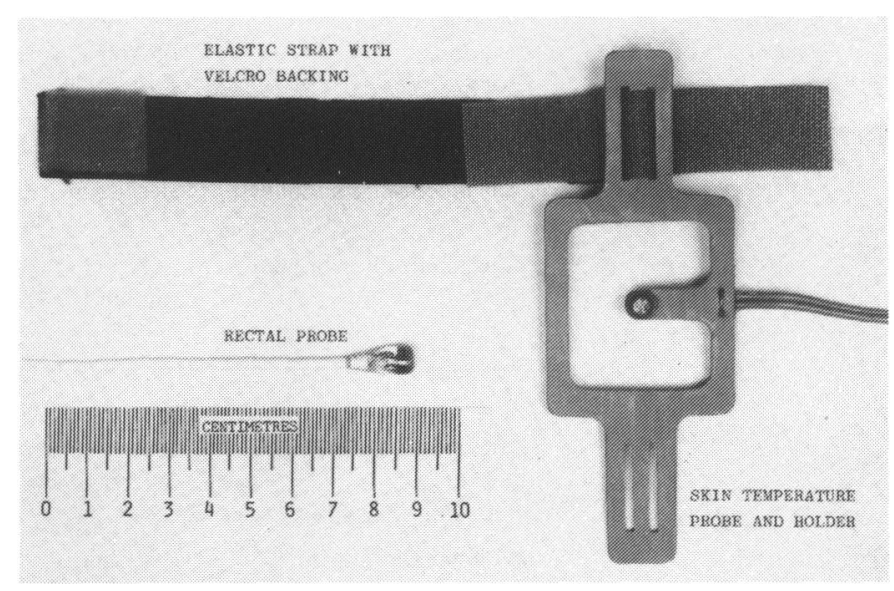

Fig. 1: The body temperature probes.

body by elastic straps with Velcro backing (Fig. 1). This system has the following advantages:

1. low mass

2. extremely flexible

3. allows air circulation around the probe together with adjacent skin area and thereby prevents false readings due to localised temperature build-up

4. the sensor itself does not interfere with heat exchange since the area of contact is only approximately $20 \mathrm{~mm}^{2}$. Although heat transfer is impeded in the region of immediate contact, conduction from adjacent skin prevents the development of a significant temperature difference if the contact area is small (Kerslake, 1982)

5. capable of being solidly attached to the skin regardless of body contour

6. remains integral throughout profuse sweating and vigorous movement.

\section{RECTAL PROBE}

A $5 \mathrm{ml}$ plastic disposable pipette tip was used as a mould for the rectal probe. The AD 590 transducer was soldered to the coaxial cable which was threaded through the enlarged tip outlet. The latter was then plugged with plasticine and a sealing compound (epoxy resin:hardener $=5: 1$ by weight and 100:22 by volume) poured into the other end up to the desired level. The plastic was cut away when the sealing compound had cured and the thermal inertia of the sensor then minimised as previously described. A sealing compound thickness of $2 \mathrm{~mm}$ at the junction with the coaxial cable has been found essential for preventing crackling due to cable movement. 
TABLE I

Materials and components

\begin{tabular}{|c|c|c|c|}
\hline Supplier & Component & Function & $\begin{array}{l}\text { Price } \\
\text { (\$A) }\end{array}$ \\
\hline $\begin{array}{l}\text { Analog Devices Inc. } \\
\text { PO Box } 796 \\
\text { Norwood } \\
\text { Massachusetts } 02062 \\
\text { USA }\end{array}$ & $\begin{array}{l}\text { AD } 590, \mathrm{H} \text { package, } \mathrm{J} \text { grade } \\
\text { ( } 2 \text { trim or calibration } \\
\text { points and } 25^{\circ} \mathrm{C} \text { range) } \\
\text { metal package }\end{array}$ & $\begin{array}{l}\text { temperature } \\
\text { transducer }\end{array}$ & $\$ 6.50$ each \\
\hline $\begin{array}{l}\text { Ciba-Geigy Australia Ltd. } \\
14 \text { Orion Road } \\
\text { Lane Cove } \\
\text { NSW } 2066 \\
\text { Australia }\end{array}$ & $\begin{array}{l}\text { Epoxy resin D } \\
\text { Hardener HY } 956\end{array}$ & $\begin{array}{l}\text { waterproof } \\
\text { sealing } \\
\text { compound }\end{array}$ & $\begin{array}{l}\$ 15.17 / \mathrm{kg} \\
\$ 3.50 / 500 \mathrm{ml}\end{array}$ \\
\hline $\begin{array}{l}\text { Radio Spares Components } \\
\text { PO Box } 99 \\
\text { Birchington Road } \\
\text { Weldon } \\
\text { Corby } \\
\text { Northants NN17 9RS } \\
\text { UK }\end{array}$ & $\begin{array}{l}35 \mathrm{~mm} \text { jack plugs (metal) } \\
\text { part no: } 478-481 \\
35 \mathrm{~mm} \text { sockets } \\
\text { part no: } 478-497\end{array}$ & $\begin{array}{l}\text { connect probe } \\
\text { cables to } 8 \text { channel } \\
\text { temperature } \\
\text { display module }\end{array}$ & $\begin{array}{l}\$ 10.15 \text { for } \\
\text { packet of } 10 \\
\$ 4.05 \text { for } \\
\text { packet of } 5\end{array}$ \\
\hline Any electronics supplier & RG 188 AU coaxial cable & $\begin{array}{l}\text { cable used for } \\
\text { rectal probe }\end{array}$ & $\$ 0.85 / m$ \\
\hline Any electronics supplier & $\begin{array}{l}\text { Ralmar LV8 } \\
\text { miniature twin or figure } 8 \\
\text { cable }\end{array}$ & $\begin{array}{l}\text { cable used for } \\
\text { skin probes }\end{array}$ & $\$ 10.28 / 100 \mathrm{~m}$ \\
\hline Any plastics supplier & $1.5 \mathrm{~mm}$ PVC sheeting & $\begin{array}{l}\text { skin probe } \\
\text { holder }\end{array}$ & nominal \\
\hline Any haberdashery store & $\begin{array}{l}2.0 \mathrm{~cm} \text { Velcro strapping } \\
2.0 \mathrm{~cm} \text { elastic }\end{array}$ & $\begin{array}{l}\text { secures skin } \\
\text { probe holder } \\
\text { to body }\end{array}$ & nominal \\
\hline $\begin{array}{l}\text { Whiteley Chemicals } \\
\text { Australia Pty. Ltd. } \\
82-84 \text { Ivy Street } \\
\text { Chippendale } \\
\text { NSW } 2008 \\
\text { Australia }\end{array}$ & Wavicide-Aid(T.M.) & $\begin{array}{l}\text { disinfecting } \\
\text { rectal probe }\end{array}$ & $\$ 12.50 / 51$ \\
\hline
\end{tabular}

* at current exchange rates $\$ A 50$ is equivalent to approximately $€ 22$.

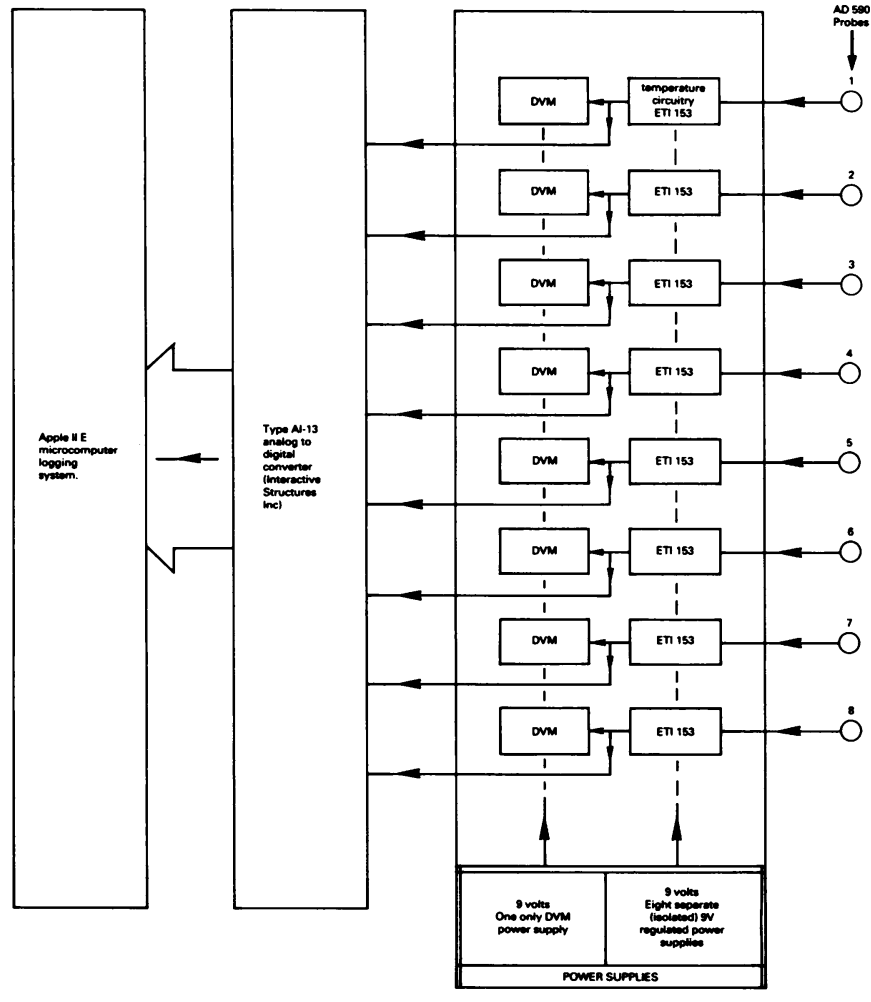

Fig. 2: Block diagram of 8 channel temperature display module.
The 4 skin probe assemblies and rectal probe (see Fig. 1) can be fabricated expediently at an approximate total cost of \$A50 (about $\mathbf{2 2}$ each) which represents a considerable saving compared with the commercially available items. Fig. 2 illustrates how the device outlined by Nicholls (1983) has been customised to our specific purpose. The resultant simultaneous digital readout of the 4 skin temperatures and rectal temperature facilitate more expedient data appraisal than possible with units having one digital readout and a channel selector knob. In our laboratory the sixth channel is used to monitor ambient temperature. The two remaining channels are calibrated for specific skin and rectal probes which serve as backups in the event of damage to other channels. It should be noted that a given temperature transducer is calibrated for one channel only and is not interchangeable with other channels.

\section{CALIBRATION}

The AD 590s were calibrated by individually immersing them in a stirred water bath immediately alongside a reference thermometer. The selected minimum and maximum calibration points for the rectal $\left(36^{\circ}\right.$ and $\left.41^{\circ} \mathrm{C}\right)$ and skin probes $\left(27^{\circ}\right.$ and $\left.36^{\circ} \mathrm{C}\right)$ were at opposite extremes of the physiological ranges of measurement. Calibration at intermediate points indicated that the sensors were accurate to within $\pm 0.05^{\circ} \mathrm{C}$. The stability of the system was such that only weekly calibration checks were required. 
Furthermore, the probes exhibited $100 \%$ response times of approximately $60 \mathrm{~s}$ to square wave stimuli of $10^{\circ} \mathrm{C}$. While the leads used in our laboratory are only $4 \mathrm{~m}$ in length, Nicholls (1983) stresses that the AD 590 transducer is particularly useful for remote sensing applications since it is insensitive to voltage drops over long lines because of its high impedance current output.

\section{SAFETY PRECAUTIONS}

After use the rectal probe was scrubbed in a warm Savlon solution to remove all traces of faeces. It was then disinfected by immersion for at least $60 \mathrm{~min}$ in undiluted, glutaraldehyde based "Wavicide-Aid(T.M.)" in accordance with the recommendations of the Australian AIDS Task Force (1985). The electronic equipment satisfied the requirements of the Standards Association of Australia (1980).

\section{References}

AIDS Task Force 1985 Infection Control Guidelines - AIDS and Related Conditions. Australian Government Publishing Service: Canberra.

Burton, A. C., 1935 "Human calorimetry II - the average temperature of the tissues of the body". J.Nutr. 9: 261-280.

Kerslake, D. McK., 1982 "Effects of climate". In: The Body at Work edited by W. T. Singleton. Cambridge University Press: Cambridge, pp. 235-297.

Nicholls, G., 1983 "Temperature adaptor for your multimeter". Electronics Today International. June: 86-89.

Ramanathan, N. L., 1964 "A new weighting system for mean surface temperature of the human body". J.Appl.Physiol. 19: 531-533.

Standards Association of Australia 1980 Australian Standard 3200 - 1980: Approval and test specifications for electromedical equipment - general requirements. Standards Association of Australia: Sydney.

Title:

\title{
BOOK REVIEW
}

Author:

\section{BACK PAIN. THE FACTS}

Publisher:

\author{
I. V. Jayson
}

Oxford University Press 1987

Price: $£ 8.95 \quad$ ISBN 0192616439

The first edition of this book was published in 1981 which, in terms of back pain research, is a long time ago. This second edition is to be commended for incorporating most of the recent advances in knowledge in the field; a feature all too rare in books which aim to provide an overview of a subject.

Professor Jayson is a rheumatologist intimately involved in numerous aspects of back pain research and his multidisciplinary interest is well reflected in an open approach to the problems and their possible solutions. The various chapters detail the scope of back pain in society, discuss the difficulties of diagnosis and itemise strategies for treatment and management. Throughout the author takes pains not to be partisan and he does not shirk acknowledgement of the limitations of our understanding of the complaint; there are no obvious gaps in the presentation. The style is pithy yet has wit, and herein lies a problem for the reviewer writing for a learned journal. To whom is the book addressed? In this case the simple answer is the 'general' reader, but this could mean either patient or practitioner. The sportsman is not immune to back pain and this book would certainly help such, often inquisitive, patients to understand their complaint and perhaps their therapists' apparent difficulty in providing an instant solution! Those practitioners working in sports medicine, who are not intimately involved with back pain research, would find the text sufficiently technical and would probably gain much from re-appraising their views in the light of the contents of this text. A book that aims to be all things to most men usually fails to be so; this one is a welcome exception.

A. Kim Burton

\section{BOOK REVIEW}

Title:

THE MEDICAL ASPECTS OF DANCE

Editors: $\quad$ D. Peterson, G. Lapenskie and A. W. Taylor

Publisher:
Price: US\$7.60
132 pages
Figs. and Tables
ISBN 0969161956

This book contains the papers presented at a conference at the University of Western Ontario, London, Canada in 1985. It is a useful book for reference in libraries but not detailed enough to have on one's bookshelf. Physiotherapists intending to branch into treatment of ballet injuries would find the section on physiology and conditioning useful.

The first section on "Dance Training Demands", describes anorexia nervosa quite well, and should, perhaps, be accessible to ballet students, as well as to teachers. From the physiotherapist's point of view, it would have been good to have seen more on dance injuries and treatment but to the student of ballet the book is interesting reading because it will encourage them to insist on early diagnosis and treatment from their physiotherapist.

The section on "Improving Ballet Performance" is worth noting and the information on pointe shoe re-design is long awaited. However, this has been found not to help established dancers as it alters their position and therefore their technique. If introduced during early training it should help prevent the ugly deformities that occur with the glue-hardened fabric box. 


\section{SECRETARY'S REPORT — Winter 1987}

The advisory Council of the Association has now met twice and the following organisations have accepted the Executive Committee's invitation to send representatives to the Council:

The National Coaching Foundation

British Association of Sport Sciences

Association of Chartered Physiotherapists in Sports Medicine

The Sports Council

London Sports Medicine Institute

The Central Council of Physical Recreation

The Institute of Sports Medicine declined our invitation to send a representative and we have yet to hear from The British Olympic Association and The British Association of National Coaches. According to the Constitution the Regions are also represented.

Our Treasurer has now managed to satisfy the Inland Revenue regarding a tax liability of the Old Association and, in accordance with the Mandate given to us, Dr. Robson (Treasurer), Dr. D. Tunstall Pedoe (Chairman) and myself (Secretary) have now formally wound up the Old Association. The remaining funds of $\mathbf{f 7 6 . 5 9}$ have been transferred to the New Company. I shall be writing to members of the Old Executive Committee up-dating the position as soon as time permits.

Dr. D. Tunstall Pedoe and I were able to accept the invitation of the Danish Sports Medicine Society to represent BASM at the Seventh Meeting of the NW European Chapter FIMS in Copenhagen on the 19th-22nd November, 1987. The Association gratefully acknowledges the assistance given by the Sports Council for travel grants to attend this meeting. Dr. Robson was also funded to be present at the Editors' Workshop and has been deputed to write up the prodeedings of the Editors' Workshop. I have been given the task of drafting a constitution for the Chapter and Dr. Tunstall Pedoe has undertaken to re-write and reenforce the text of the written proposals and initiative by the Flemish Association regarding their campaign against doping.

Dr. Tunstall Pedoe has accepted the BASM Executive Committee's invitation to be the Association's spokesman on doping. The Executive Committee, on a proposition brought forward from the Council Meeting by Dr. M. Bottomley on behalf of the SW Region, have instructed the Secretary to correspond with the Registrar of Companies and Charity Commission in an effort to modify the Constitution in that it would no longer be necessary for any aspiring officer or member of the Executive Committee to collect twelve signatories to their nomination. Article 47 of the Constitution - the minimal acceptable number is being sought.

A meeting of the Editorial Board is being called to investigate further the professionalisation of the Journal.

David P. Chapman

\section{ERRATUM}

Gore, C. J., Withers, R. T., Woods, G. F. and Day, L. (1987)

Inexpensive probes for the determination of body temperature. BJSM 21: 127-129.

The editors regret the following errors in this paper:

p. 127 ... cracking due to cable movement

Table I last line of last column should read $\$ 12.50 / 5 \mathrm{~L}$

p. 128 third line of text - delete "each" 